\title{
PKD1L2 Gene
}

National Cancer Institute

\section{Source}

National Cancer Institute. PKD1L2 Gene. NCI Thesaurus. Code C150295.

This gene may play a role in calcium channel regulation and $\mathrm{G}$ protein-coupled receptor activity. 